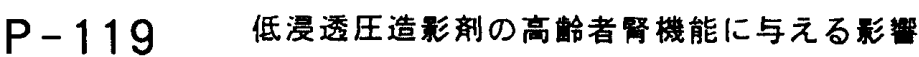

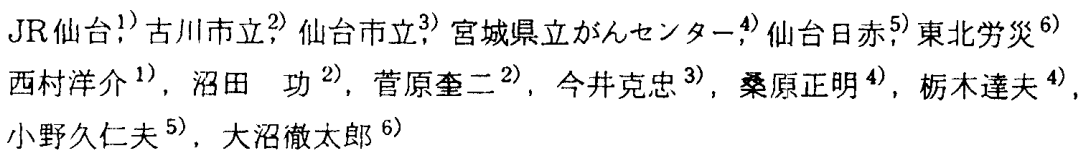

【目的】造影剂の投与が腎機能を障害する可能性があり，予備能の低下した高齢者ではその影響が大 きいととも考えられるので検討した。

【対象】種々の泌尿器科的疾患を有する75才以上の入院患者 134 例を対象とした。その平均年令士 SD は80.0土3.7才，性別は男 113 例女 21 例である。

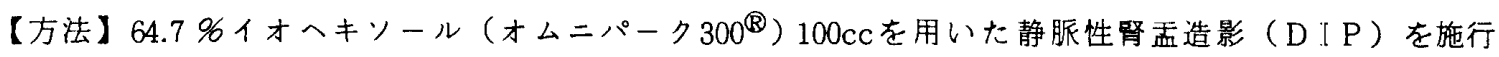
する前後で血清クレアチニン，BUN， Na，K，Cl，24時間クレアチニンクリアランス（CClR）を測定し その差の大ささと統計学的な有意性を検討した。クレアチニン，BUN，CCRについては，変動量に対 して年令と前值の与える影響についても検討した。統計学的手法は対応のあるt検定，2元配置分散分 析，回帰分析を用いた。

【結果】有意水準 596 として有意差があったのは， $\mathrm{Na} 、 \mathrm{~K}, \mathrm{Cl}, \mathrm{BUN} の 4$ 項目であったが，前 3 者の変 化の絶対值は小さく, 臨床上す有意なのはBUNの変化(平均 $-1.5 \mathrm{mg} / \mathrm{dl}, 95 \%$ 信頼区間 $-2.3 \sim-0.7$, 有 意確率 0.006)のみであり，それは堅機能改善の方向への变化であった。各検討項目の前後変化の方向 は, 低値の側では增加方向, 高值の側では減少方向となる傾向を示したが, 変化量に対する年令の影 镖はなかった。

【結論】造影剂の投与による堅機能への影響は，高齢者においても臨沫上重大な屯のが法現する可能 性は小さいと思われた。

\section{$P-120$ 糸球体性疾患における尿中赤血球形態の楛討}

鳥取大学 ${ }^{11}$ 、同小児科 ${ }^{2)}$

平川真治 ${ }^{11}$ 、田丸佼三 ${ }^{11}$ 、林原 博 $^{21}$ 、宮川征男 ${ }^{11}$

【目的】系球体性疾患の尿中赤血球形態をリアルタイム共焦点型レーザー顕微鏡を用いて梌討した。

【対象と方法】最近、当院に受診した系球体性疾患症例 29 例を対象とした。年㱓は4〜20歳で平均 12.4 歳、女性 16 例、男性 13 例であった。系球体性疾患の内訳は、IgA腎症（IgAN）12例、巣状 增殖性腎炎（FGN）8例、紫班病性腎炎（HSPN）6例、その他 3 例であった。これらの症例に対して、 レーザー検尿（リアルタイム共焦点型レーザー顕微鏡を用いた尿中赤血球形態観察）を行なった。尿中 赤血球の形態をThielらの分類にもとづいて判定した。つまり、系球体性赤血球はG1 G11の11の タイプに分類されるわけである。また、血尿由来の判定は石原らの判定基準にもとづき、尿中変形（糸 球体性）赤血球が $70 \%$ 以上を占める場合を系球体性、尿中正常赤血球が $70 \%$ 以上占女る場合を非 系球体性、西者の中間を混合性のパターンとした。

【結果】レーザー検尿では、29例中 10 例 (34.5\%) が糸球体性、10 例 $(34.5 \%)$ が非系球体性、 9例 $(31.0 \%)$ が混合性のパターンを示した。尿中の系球体性赤血球のタイプの割合は、全体ではG 2 、 G 1、G 3、G 5 の順に多く、IgANではG 2、G3、G 1、G 4、FGNでは ではG 2、G1、G3、G7の順に多かった。今後、さらに症例を追加して検討していく予定である。 